\title{
Studi Perbandingan Eksistensi Alam Pada Novel Tanah Baru Tanah Air Kedua Karya Nh. Dini Dan Sri Rinjani Karya Eva Nourma (Tinjauan Ekologi Sastra)
}

\author{
Eka Yulianti', Taufik ${ }^{2}$ \\ 1,2, Dosen Program studi Pendidikan Bahasa Sastra Indonesia, STKIP Yapis Dompu \\ E-mail: eka24547@gmail.com, taufikbima25gmail.com
}

Article History: Received: 2020-10-09 || Revised: 2020-11-03 || Published: 2020-11-17

Sejarah Artikel : Diterima: 2020-10-09 || Direvisi: 2020-11-03 || Dipublikasi: 2020-11-17

\begin{abstract}
The purpose of this research is (1) to explain the comparative aspect of natural components revealed in the novel Tanah Baru Tanah Air Dua by Nh. Dini and the novel Sri Rinjani by Eva Nourma; (2) the comparative aspect of character interaction in the environment revealed in the novel Tanah Baru Tanah Air Dua by Nh. Dini and the novel Sri Rinjani by Eva Nourma; (3) describes the comparative aspect of the educational value of human attitudes towards nature, which is revealed in the novel Tanah Baru Tanah Air Dua by Nh. Dini and the novel Sri Rinjani by Eva Nourma. The approach used is a qualitative approach with descriptive methods. The data source of this research is the novel Tanah Baru Tanah Air Dua by Nh. Dini and the novel Sri Rinjani by Eva Nourma. The research data is in the form of a series of stories. Based on the data analysis and discussion, three things can be concluded. First, the comparison of the natural components revealed by Nh. Dini in the novel Tanah Baru Tanah Air Dua predominantly shows the use of nature in exploitation and economic patterns, while the novel Sri Rinjani by Eva Nourma shows more dominantly the use of nature to support the economy. Second, the comparison of character interactions in the environment as revealed in the novel Tanah Baru Air Keduakarya Nh. Dini is more dominant in showing a reciprocal relationship that affects each other, while the novel Sri Rinjani by Eva Nourma is more dominant in showing a reciprocal relationship that communicates with each other. Third, a comparison of the educational value of human attitudes towards nature is revealed by the novel Tanah Baru Tanah Air Dua by Nh. Dini predominantly shows the preservation of the natural environment, while the novel Sri Rinjani by Eva Nourma is more dominant in appreciating the natural environment.
\end{abstract}

\section{Keywords: Comparison, Nature's Existence, Natural Components, Character Interaction, Educational Value}

\begin{abstract}
Abstrak
Tujuan penelitian ini adalah (1) menjelaskan aspek perbandingan komponen kealaman diungkapkan pada novel Tanah Baru Tanah Air Kedua karya Nh. Dini dan novel Sri Rinjani karya Eva Nourma; (2) aspek perbandingan interaksi tokoh pada lingkungan diungkapkan pada novel Tanah Baru Tanah Air Kedua karya Nh. Dini dan novel Sri Rinjani karya Eva Nourma; (3) aspek perbandingan nilai edukatif penyikapan manusia terhadap alam diungkapkan pada novel Tanah Baru Tanah Air Kedua karya Nh. Dini dan novel Sri Rinjani karya Eva Nourma. Pendekatan yang digunakan adalah pendekatan kualitatif dengan metode deskriptif. Sumber data penelitian ini ialah novel Tanah Baru Tanah Air Kedua karya Nh. Dini dan novel Sri Rinjani karya Eva Nourma. Adapun data penelitiannya berupa rangkaian cerita. Berdasarkan analisis data dan pembahasan yang dilakukan, maka dapat disimpulkan tiga hal. Pertama, perbandingan komponen kealaman yang diungkapkan Nh. Dini dalam novel Tanah Baru Tanah Air Kedua lebih dominan menunjukkan pemanfaatan alam dalam pola eksploitasi dan perekonomian, sedangkan novel Sri Rinjani karya Eva Nourma lebih dominan menunjukkan pemanfaatan alam untuk penunjang perekonomian. Kedua, perbandingan interaksi tokoh pada lingkungan yang diungkapkan dalam novel Tanah Baru Tanah Air Keduakarya Nh. Dini lebih dominan menunjukkan hubungan timbal balik yang saling mempengaruhi, sedangkan novel Sri Rinjani karya Eva Nourma lebih dominan menunjukkan hubungan timbal balik yang saling berkomunikasi. Ketiga, perbandingan nilai edukatif penyikapan manusia terhadap alam diungkapkan novel Tanah Baru Tanah Air Kedua karya Nh. Dini lebih dominan menunjukkan pelestarian lingkungan alam, sedangkan novel Sri Rinjani karya Eva Nourma lebih dominan menghargai lingkungan alam.
\end{abstract}

Kata kunci: Perbandingan, Eksistensi Alam, Komponen Kealaman, Interaksi Tokoh, Nilai Edukatif. 


\section{PENDAHULUAN}

Sudah sejak lama alam menjadi bagian representasi dari banyak karya sastra. Alam sering kali tidak sekadar menjadi latar sebuah cerita-cerita fiksional dalam karya sastra, tetapi juga dapat menjadi tema utama dalam sebuah karya sastra. Pilihan diksi seperti air, pepohonan, sungai, ombak, awan, dan kata-kata lain memperlihatkan bahwa alam dimanfaatkan oleh sastrawan untuk menggambarkan latar ataupun isi yang ada dalam karya sastra itu sendiri. keterkaitan alam dengan karya sastra memunculkan sebuah konsep tentang permasalahan ekologi dalam sastra, di antara para kritikus sastra. Ekologi dapat diartikan sebagai kajian ilmiah tentang pola hubunganhubungan tumbuh-tumbuhan, hewan-hewan, dan manusia terhadap satu sama lain dan terhadap lingkungannya. Menurut Croall dan Rankin (Via Harsono, 2008:35), ekologi mencakup rangkaian ilmu alam, ilmu sosial, filsafat, dan pengetahuan menyeluruh. Pendekatan holistiknya membuat ilmu ini menjadi luas. Pokok utama yang dibahas dan menjadi pusat adalah kesaling tergantungan semua makhluk hidup. Seperti cakupan lingkungan itu dapat sempit, terbatas, tetapi dapat juga luas tidak terbatas, maka ekologi dapat membatasi diri pada rangkuman yang sempit, namun dapat juga meliputi wilayah yang sangat luas (Dwidjoseputro, 1991:8). Novel karya Tanah Baru Tanah Air Kedua dan novel Sri Rinjani merupakan bentuk karya sastra yang memiliki manfaat bagi masyarakat. Manfaat itu dapat dilihat pada nilai-nilai edukatif yang ada di dalamnya. Nilai-nilai edukatif ini yang nantinya mampu mempengaruhi sikap dan tingkah laku manusia dalam masyarakat. Guru bahasa dan sastra Indonesia sebagai tenaga pendidik dapat dijadikan pengarah untuk mengajarkan nilai-nilai edukatif dalam karya sastra. Oleh karena itu, tugas pengajar tidak sekedar menyampaikan informasi, melainkan bisa membentuk dan membimbing peserta didiknya menjadi manusia yang berbudi luhur dan beretika (Muhamad Soerjani, 2009:115). Melalui novel guru dapat mengajarkan sastra dengan memilah-milah novel yang mengandung nilai-nilai edukatif yang hasilnya dapat diterapkan siswa dalam kehidupan sehari-hari sehingga siswa memiliki kepribadian yang baik..

Beberapa sastrawan Indonesia menjadikan alam dan lingkungan sebagai bagian yang penting dalam karya-karyanya. Hampir seluruh penulis fiksi menggunakan objek alam sebagai media untuk menuangkan sebuah ide dalam sebuah karyanya (Kaswadi, 2016;20) Dalam novel, Nh. Dini sebagai pengarang mampu menghadirkan lingkungan fisik dan sosial yang memiliki perluasan yang mengejutkan. Dengan memanfaatkan latar material dan latar tempat pengarang menghadirkan tokoh yang mampu berpikir kritis. Di samping itu, ia juga menyajikan kesadaran akan pentingnya menjaga dan melestarikan alam, berintraksi dengan baik, dan mampu memberikan nilai-nilai positif untuk pembaca. Nh. Dini menggunakan media bahasa dalam memamparkan alam dengan terperinci sehingga pembaca dapat dengan jelas merasakan keadaan yang ada dalam cerita. Berbeda dengan Eva Nourma, lewat karyanya Sri Rinjani membuka wawasan mengenai lingkungan masyarakat yang hidup di kawasan pesisir. Sebagai pengarang Eva Nourma memiliki ciri khas tersendiri. Setiap karyanya memuat hal-hal yang menarik yang mengandung unsur-unsur yang membangun untuk bertahan hidup di lingkungan pesisir. Pembaca dapat mengambil nai-nilai positif dalam karyanya. Cerita ini mengilhami penulis untuk mengkaitkan dengan ekologi sastra yang mulai ramai di perbincangkan dan dibahas dalam bidang sastra.

Ekologi yang terjadi di Pulau Kalimantan dan Pulau Lombok melahirkan keprihatinan berbagai kalangan disiplin ilmu. Kepedulian berbagai disiplin ilmu yang menitikberatkan pada pola terbentuknya degradasi lingkungan dengan dampak-dampak yang dihasilkan dari fenomena tersebut merupakan suatu kajian yang dijadikan awal keberangkatan dari setiap kajian yang berlangsung. (Imam Supardi, 2003;15) Satu di antara berbagai respon yang diberikan oleh suatu disiplin ilmu, yaitu melalui perspektif sastra. Kecenderungan sastra dalam melihat berbagai fenomena sosial masyarakat yang bertolak dari isu-isu lingkungan, juga akan membuktikan bahwa 
sastra sebagai dunia imaji pengarang telah merangkul berbagai pendekatan untuk melihat isu-isu yang melatarbelakangi masalah yang terjadi dalam aktivitas sosial masyarakat. Representasi sastra dalam menggambarkan kepedulian atas degradasi alam yang memengaruhi aktivitas sosial masyarakat dilakukan oleh para penggiat sastra dengan melahirkan karya dengan isu-isu degradasi ekosistem di Pulau Kalimantan.

Penelitian mengenai studi perbandingan dengan keberadaan ekologi sebagai media dalam pemertahanan kelangsungan hidup, merupakan perhatian utama peneliti dalam menangkap fenomena sosial yang terdapat di dalam karya sastra dalam bentuk novel sebagai gejala sosial di tengah masyarakat. Melalui proses pencarian dan pembacaan dua isi novel yang berbeda untuk di bandingkan. Peneliti memilih dua novel yang menempatkan latar penceritaan di Pulau Kalimantan yaitu novel "Tanah Baru Tanah Air Kedua" karya Nh. Dini dan novel "Sri Rinjani” di pulau lombok karya Eva Nourma sebagai objek penelitian, kedua novel tersebut memiliki sudut penceritaan yang didominasikan pada lingkungan alam.

\section{METODE PENELITIAN}

Pendekatan yang digunakan dalam penelitian ini adalah pendekatan kualitatif, karena penelitian yang digunakan tentang studi perbandingan. Analisis data bersifat induktif berdasarkan hubungan antarfenomena yang diamati dengan menggunakan logika ilmiah, serta penelitian ini lebih menekankan proses daripada hasil. Hal ini sesuai dengan pendapat Sugiono (2010: 15) menyebutkan, pendekatan kualitatif sebagai pendekatan yang digunakan untuk meneliti objek yang alamiah (sebagai lawan dari eksperimen), peneliti sebagai instrumen kunci, teknik pengumpulan data dilakukan secara triangulasi (gabugan). Analisis data bersifat induktif, serta pada analisis terhadap dinamika hubungan antarfenomena yang diamati dengan menggunakan logika ilmiah, hasil penelitian lebih menekankan pada makna daripada generalisasi.

Indikator-indikator penelitian merupakan hal yang penting dalam suatu penelitian. Hal tersebut bertujuan agar penelitian tetap berfokus pada rumusan masalah yang telah dibuat. Indikator-indikator peneliti terkait dengan masalah yang akan diteliti sebagai berikut.

Tabel 1. Indikator Permasalahan

\begin{tabular}{|c|c|c|c|}
\hline No & Aspek Pengkajian & Fokus Penelitian & Indikator \\
\hline 1 & Komponen Kealaman & Pemanfaatan alam & $\begin{array}{ll}\text { - } & \text { Penunjang } \\
& \text { perekonomian } \\
- & \text { Eksplorasi } \\
\end{array}$ \\
\hline 2 & Interaksi Tokoh & $\begin{array}{l}\text { Hubungan timbal balik } \\
\text { antara tokoh }\end{array}$ & $\begin{array}{ll}- & \text { Saling } \\
\text { mempengaruhi } \\
\text { - } & \text { Saling } \\
& \text { berkomunikasi } \\
\text { - } & \text { Tindakan dan } \\
& \text { reaksi tokoh } \\
\end{array}$ \\
\hline 3 & $\begin{array}{l}\text { Perbandingan Nilai Edukatif } \\
\text { Penyikapan } \\
\text { ManusiaTerhadap } \\
\text { Lingkungan Alam }\end{array}$ & Pelestarian lingkungan alam & $\begin{array}{ll}\text { - } & \text { Melindungi } \\
& \text { lingkungan alam } \\
\text { - } & \text { Melestarikan } \\
& \text { lingkungan alam }\end{array}$ \\
\hline
\end{tabular}


Tabel 2. Instrumen Penyajian Data Eksistensi Alam

\begin{tabular}{cll}
\hline No & Indikator Permasalahan & Data \\
\hline \multirow{2}{*}{1} & \multirow{2}{*}{ Pemanfaatan Alam } & TBTAK/PA-1/2014: 32 \\
& & SR/PA-1/2011: 1 \\
\hline \multirow{2}{*}{2} & Interaksi Tokoh Pada & TBTAK/ITPL-2/2014: 32 \\
& Lingkungan & SR/ITPL-2/2011: 1 \\
\hline \multirow{2}{*}{3} & \multirow{2}{*}{ Pelestarian Lingkungan Alam } & TBTAK/PLA-3/2014: 32 \\
& & SR/PLA-3/2011:1 \\
\hline
\end{tabular}

$\begin{array}{ll}\text { Keterangan: } \\ \text { TBTAK } & \text { : Tanah Baru Tanah Air Kedua } \\ \text { SR } & \text { : Sri Rinjani } \\ \text { PA } & \text { : Pemanfaatan Alam } \\ \text { ITPL } & \text { : Interaksi Tokoh Pada Lingkungan } \\ \text { PLA } & \text { : Pelestarian Lingkungan Alam }\end{array}$

Kode-kode tersebut untuk memudahkan dalam mengumpulkan data, sehingga dapat lebih muda memahami. Berikut ini maksud dari pengkodean tersebut.

1) TBTAK, judul novel Tanah Baru Tanah Air Kedua sebagai objek penelitian.

2) SR, judul novel Sri Rinjani sebagai objek penelitian.

3) PA-1, menunjuk pada data pertama yang digunakan.

4) ITPL-2, menunjuk pada data kedua yang digunakan.

5) PLA-3, menunjuk pada data ketiga yang digunakan.

6) 2014 dan 2011 menunjuk pada tahun terbit novel yang diteliti.

7) Angka setelah tahun 2014 dan 2011 merupakan halaman data yang diperoleh dari novel.

Teknik pengumpulan data yang digunakan dalam penelitian ini adalah teknik eksplorasi. Dalam teknik ini, data-data yang ada dalam novel dieksplorasi. Data-data tersebut tentunya disesuaikan dengan rumusan masalah yang dikaji. Teknik analisis data menurut Patton (dalam Ismawati, 2012:15) merupakan proses mengatur data, mengorganisasikan ke dalam suatu pola, kategori dan satuan uraian dasar.

\section{HASIL DAN PEMBAHASAN}

A. Aspek Perbandingan Komponen Kealaman yang Diungkapkan dalam Novel Tanah Baru Tanah Air Kedua Karya Nh. Dini dan Novel Sri Rinjani Karya Eva Nourma.

1. Aspek Komponen Kealaman yang Diungkapkan dalam Novel Tanah Baru Tanah Air Kedua Karya Nh. Dini.

Novel Tanah Baru Tanah Air Kedua karya NH. Dini adanya pemanfaatan alam bagi manusia untuk kepentingan pribadi atau individu dari cara masyarakatnya berladang serta menebang pohon untuk melangsungkan kehidupannya. Pada awal cerita nampak permasalahan yang terjadi pada tokoh. Seperti yang dipaparkan pada kutipan di bawah ini.

(1) Samirin sekarang menyaksikan dan merasakan bahwa pembangunan harus diratakan. Menuju Kintap, jalan itu melewati berpuluh batang air. Sungai besar dan beberapa. Yang lebar, semuanya dalam dan terletak lebih rendah dari jalan.

(TBTAK/KK-1/2014: 36)

Berdasarkan analisis di atas pemanfaatan alam cenderung kearah eksplorasi yang dilakukan tokoh Samirin dan anggota transmigrasi dalam memanfaatkan hutan di 
Kalimantan untuk melakukan penebangan pohon ulin. Hal ini dibuktikan oleh kutipan berikut.

(2) "Kintap penuh dengan hutan ulin. Banyak perusahaan penebangan di sana."

"Perusahaan asing?"

"campuran. Ada asing dan orang-orang kita. Hampir semua penduduk Kintap bekerja di perkayuan.

(TBTAK/KK-1/2014: 37)

Analisis di atas lebih merujuk pada pola eksplorasi yang dilakukan oleh anggota transmigrasi di Kalimantan. Penebangan pohon ulin sebagai salah satu dari mata pencarian para transmigrasi, selain dari berladang dan tempat tinggal yang telah dibagikan oleh pemerintah di Kalimantan. Hal tersebut tampak pada kutipan berikut.

(3) Jatah itu tidak berupa pembagian makanan, melainkan seluasan tanah. Yang sudah nyata adalah rumah beserta pekarangan itu sendiri, keseluruhannya seperempat hektar. Satu tiga perempat lainnya akan diterimakan dalam bentuk lotre.

(TBTAK/KK-1/2014: 42)

Penunjang perekonomian yang digambarkan Nh. Dini pada tokoh Samirin dan Anggota transmigrasi dapat dilihat dari pemanfaatan lahan pertanian untuk dilakukan penanam bibit yang sesuai dengan keadaan ladang yang telah dibagikan.

\section{Aspek Komponen Kealaman yang Diungkapkan dalam Novel Sri Rinjani Karya Eva Nourma.}

Novel Sri Rinjani karya Eva Nourma menceritakan bagaimana tokoh Sri Rinjani yang dibesarkan di sebuah bukit gunung rinjani yang jauh dari hiruk piruk perkotaan di pulau Lombok. Sri Rinjani yang terlahir dari orang tua yang sangat miskin dan tidak berpendidikan. Orang tua Sri Rinjani mencari nafkah sehari-sehari sebagai pencari ikan di laut. Sri Rinjani juga memiliki ladang tapi tidak seberapa dari hasil warisan yang diberikan oleh kakeknya. Sedangkan ibunya mencari nafkah sebagai memukul batu yang penghasilannya, untuk makan setiap hari saja tidak cukup. Ciri-ciri aspek komponen kealaman yang dimunculkan dalam novel Sri Rinjanikarya Eva Nourama ialah adanya pemanfaatan alam yang ada di pulau Lombok. Hal tersebut tampak pada kutipan dibawah ini.

(1) Tidak sedikit warga Selayar mengais rizki sebagai penambang batu apung dan batu hitam di pinggir pantai. Ini adalah rutinitasyang harus dilakoni sebagai penyambung hidup.

(SR/KK-1/2011: 3)

Melalui kutipan di atas, novel Sri Rinjani menggambarkan bagaimana tokoh dalam novel memanfaatkan alam untuk penunjang perekonomian. Pemanfaatan alam tersebut dengan cara menambang batu apung atau batu hitam di pinggir pantai. Hasil alam yang melimpah di wilayah tersebut dimanfaatkan masyarakat untuk dapat menyambung hidup. melalui tokoh dalam novel tergambar bagaimana hasil alam yang bertebaran di lingkungan sekitar masyarakat dapat memiliki nilai yang berharga.

(2) Selayar bukan daerah pertania. Jika pun ada warga bertani, itu benar-benar dipaksakan. Sebab selayar semulut dengan lautan. Maka pilihan hidup seolah satu. Warga memilih menjadi buruh pemecah batu dan nelayan.

(SR/KK-1/2011: 4) 
Berdasarkan kutipan tersebut, Eva Nourma dalam novelnya menggambarkan bagaimana tokoh dalam novel melakukan eksplorasi terhadap lingkungan sekitar mereka. Tokoh dalam novel digambarkan memanfaatkan alam dengan optimal sesuai dengan situasi dan kondisi. Di daerah pantai memang akan sulit melakukan pertnian, walaupun hasilnya dianggap lebih menjanjikan akan tetapi hal tersebut tidak didukung oleh jenis tanah dan lingkungan tersebut. Daerah pantai pemanfaatan alamnya secara utama adalah hasil laut dan bebatuan tersebut. Hasil eksplorasi dari pemanfaatan alam inilah yang menjadi mata pencaharian utama bagi masyarakat di Selayar yang digambarkan Eva Nourma dalam novel Sri Rinjani.

(3) Batu-batu yang sudah dipecah akan dibayar seribu rupiah perbakulnya. Atau empat ratus ribu untuk satu dam truk.

(SR/KK-1/2011: 6)

Kutipan tersebut menunjukkan bahwa pemanfaatan alam tidak dapat memenuhi kebutuhan ekomoni masyarakat secara optimal. Penghasilan yang didapatkan melalui pekerjaan kasar tersebut tidak mendapatkan imbalan yang setimpal. Eva Nourma dalam novelnya menggambarkan pemanfaatan alam oleh tokoh tidak dapat menunjang perekonomian masyarakat setempat dengan optimal. Masyarakat desa Selayar hanya mencari nafkah dengan cara memukul batu yang hasil jualnya tidak sebanding dengan cara kerjanya yang cukup menguras tenaga.

\section{B. Aspek Perbandingan Interaksi Tokoh pada Lingkungan yang Diungkapan dalam Novel Tanah Baru Tanah Air Kedua Karya Nh. Dini.}

1. Aspek Interaksi Tokoh pada Lingkungan yang Diungkapkan dalam Novel Tanah Baru Tanah Air Kedua Karya Nh. Dini.

Interaksi tokoh yang muncul dalam novel Tanah Baru Tanah Air Kedua karya Nh. Dini merujuk pada bagaimana tokoh saling mempengaruhi antara satu sama lain,untuk bisa bertahan hidup di tempat rantauan.

Tokoh Samirin dalam novel Tanah Baru Tanah Air Kedua merupakan tokoh yang berperan penting terhadap lingkungan yang ada di pulau Kalimantan. Samirin melakukan pengarahan dan mempengaruhi anggota transmigrasi dalam berladang dan memanfaatkan hasil bumi yang ada di pulau Kalimantan.

(1) Kayu ulin, Mas! Tidak seperti kayu yang ada di Jawa!" kata orang dari Jember. "Keras, kuat tahan lama. Semua nilai ada padanya. Dalam pelajaran sekolah, Samirin tidak pernah diberi tahu bahwa hasil Pulau Kalimantan adalah kayu ulin. Selalu dikatakan kayu besi.

(TBTAK/HTB-2/2014: 37)

Kutipan tersebut menunjukkan bahwa tokoh Samirin sebagai pendatang baru ingin mengetahui bagaiamana kondisi serta situasi yang ada di daerah Kintap tepatnya di pulau Kalimatan. Samirin dan tokoh lainnya saling berkomunikasi tentang bagaimana keadaan Kintap dan apa saja yang bisa di manfaatkan untuk menyambung hidup di Kintap. Di pulau kalimantan kaya dengan hasil kayu ulinnya. Banyak pendatang yang memanfaatkan kayu ulin untuk mencari nafkah.

(2) Samirin telah siap membantah lagi, tetapi kali itu giliran Wakijan yang menonjokkan siku keperutnya. Samirin jengkel menghadapi pendapat yang tidak mengingati kepentingan orang lain.

(TBTAK/HBT-2/2014: 39) 
Kutipan tersebut menunjukkan bahwa bagaimana reaksi tokoh Samirin terhadap ucapan yang dilontarkan oleh orang Jember tentang pembabatan hutan demi mengais rezeki di daerah rantauan. Samirin merasa kecewa karena telah memberitahukan kalau untuk penebangan pohon di hutan harus ada penanaman kembali supaya tidak terjadi bencana alam. Tapi orang Jember tetap saja membatah Samirin karena walaupun ditebang bertahuntahun tidak akan kenapa-kenapa, lagi pula itu masih lama karena hutan di pulau Kalimantan sangat luas, jadi semasih bisa di manfaatkan dan di hasilkan sebagai uang kenapa tidak untuk mereka tebang.

(3)Apalagi orang Banjar itu mengandalkan penebangan sebagai sumber pencarian. Kalau Samirin berkeras kepala menjubalkan pengetahuannya, akan berakhir dengan percekcokan.

(TBTAK/HBT-2/2014: 39)

Kutipan tersebut menunjukkan bahwa tokoh Samirin sangat kecewa dengan pendapat yang menurut dirinya tidak baik untuk mereka sendiri. Tapi untungnya ada Wakijan yang siap menenangkan emosinya ditengah anggota trans, kalau tidak Samirin tetap kekeh untuk mempertahankan pengetahuannya ditengah orang-orang yang mungkin tidak mengenal bangku sekolah. Apalagi semua orang yang bertransmigrasi di pulau Kalimantan mengandalkan hutan sebagai sumber pemanfaatannya untuk mencari nafkah. Untuk itu Samirin terdiam sejenak memikirkan apa yang Wakijan katakan. Hal itu tampak pada kutipan dibawah ini.

(4) Disitu terkumpul lipatan kertas putih kecil-kecil. Mereka disuruh menarik nomor bagian tanah. Setelah mendapat nomor, disertai kode-kode abjad yang maknanya hanya dimengerti oleh orang bersangkutan di dalam sekatan itu, mereka harus menunggu lama lagi.

(TBTAK/HBT-2/2014: 43)

\section{Aspek Interaksi Tokoh pada Lingkungan yang Diungkapkan dalam Novel Sri Rinjani Karya Eva Nourma.}

Novel Sri Rinjani karya Eva Nourma menceritakan bagaimana tokoh Sri Rinjani hanya saling interaksi bersama neneknya tentang bagaimana keadaan Lombok dulu dan apa saja yang menjadi mata pencarian orang di Desa Perigi. Begitupun dengan ayahnya Sri hanya disuruh menemani ayahnya melihat ladang. Itulah kehidupan yang Sri lalui di desa Perigi. Ciri-ciri aspek interaksi tokoh pada lingkungan yang dimunculkan dalam novel Sri Rinjani karya Eva Nourama ialah adanya hubungan timbal balik antara tokoh yang ada di Lombok. Hal tersebut tampak pada kutipan dibawah ini.

(1) Pada suatu sore di musim hujan yang berkabut, ayah mengajakku ke ladang untuk memeriksa tanaman jagungnya terendam atau tidak oleh air hujan lebat semalam. Kami melewati jalan lebarnya hanya setengah meter. Aku berjalan dengan sangat hatihati karena tanahnya licin.

(SR/HTB-2/2011: 19)

Kutipan tersebut menunjukkan bahwa tokoh Sri Rinjani seorang anak yang sangat patuh kepada orang tua. Walaupun dia seorang wanita tapi ayahnya berharap Sri Rinjani tetap menjadi wanita yang kuat seperti seorang laki-laki. Karena hidup tidak akan pernah berhasil kalau tidak berusaha dan memanfaatkan waktu untuk belajar menghadapi hari esok. 
(2) “Nama Sri Rinjani memberimu alamat pulang, anakku.Sejauh mana pun kamu pergi, ayah berharap kamu akan pulang untuk membangun pulau ini dengan potensi yang kamu miliki.

(SR/HTB-2/2011: 20)

Kutipan diatas menunjukkan bahwa Sri Rinjani merasa malu dengan nama yang telah diberikan oleh ayahnya. Nama Sri Rinjani memiliki arti yang sangat berarti untuk ayah dan hidupmu kelak. Harapan ayahnya dengan nama Sri Rinjani dia akan mengenal jati dirinya ketika dia hendak pergi dari desa Perigi. Sri Rinjani akan tau tempat tinggalnya di lereng gunung Rinjani dan kembali mengingat tanah kelahirannya. Suatu saat nanti Sri Rinjani akan bisa mengubah desa Perigi ini menjadi jauh lebih baik dari sekarang. Hal tersebut tampak pada kutipan dibawahini.

(3) “Lombok tidak miskin, anakku. Hanya saja Lombok belum memiliki manusia yang tangguh serta benar-benar memiliki keinginan kuat untuk membangun pilau ini."

(SR/HTB-2/2011: 21)

Kutipan tersebut, menunjukkan bahwa harapan ayahnya Sri Rinjani akan nasib mereka yang tinggal di desa Perigi tepatnya di pulau Lombok gunung Rinjani. Suatu saat nanti akan ada yang bisa memberikan warna indah untuk desa Perigi. Karena menurut ayahnya Sri Rinjani lombok dan desa mereka sebenarnya memiliki potensi alam yang cukup banyak untuk dimanfaatkan sebagai mata pencarian.

(4) Dalam perjalanan yang kami lanjutkan, kami tidak lagi berbicara sepatah kata pun sampai kami tiba di ladang yang ditumbuhi jagung. Ayah tersenyum puas karena jagungnya tidak rusak oleh hujan lebat semalam.

(SR/HTB-2/2011: 22)

Kutipan tersebut, menunjukkan bahwa kepuasan ayah Sri Rinjani akan hasil ladangnya yang tidak rujak diterpa hujan dan angin kencang. Tidak sia-sia Sri Rinjani dan ayahnya ke ladang. Sri Rinjani selain mendapatkan jawaban dari semua peryantaannya, sekarang Sri Rinjani pun merasa bahagia melihat ayahnya bersyukur ladangnya tidak kenapa-kenapa.

\section{Aspek Perbandingan Nilai Edukatif Penyikapan Manusia Terhadap Lingkungan Alam pada Novel Tanah Baru Tanah Air Kedua Karya Nh. Dininovel Sri Rinjani karya Eva Nourma.}

1. Aspek Perbandingan Nilai Edukatif Penyikapan Manusia Terhadap Lingkungan Alam pada Novel Tanah Baru Tanah Air Kedua Karya Nh. Dini.

Nilai edukatif penyikapan manusia terhadap lingkungan yang muncul dalam novel Tanah Baru Tanah Air Kedua karya Nh. Dini merujuk pada bagaimana cara tokoh menjaga dan melestarikan lingkungan alam yang terdapat pada pulau Kalimatan.

Tokoh Samirin yang diungkapkan dalam novel Tanah Baru Tanah Air Kedua, merupakan tokoh yang sangat berperan penting dalam segala hal yang terjadi pada lingkungan yang ada di pulau Kalimantan. Dimana Samirin melakukan pengarahan kepada anggota trans akan pentingnya alam dalam kehidupan kita. Ketika manusia memanfaatkan hasil alam dengan cara menebang pohon, mereka harus menanam kembali pohon yang ditebang supaya tidak terjadi bencana yang bisa merugi manusia. Hal tersebut tampak pada kutipan dibawah ini.

(1) Apakah dilakukuan penanaman kembali bibit-bibit ulin? Karena banyak yang ditebang, kan harus ditumbuhkan yang baru.

(TBTAK/PLA-3/2014: 38) 
Kutipan tersebut, menunjukkan bahwa tokoh Samirin begitu kecewa dengan anggota transmigrasi yang mencari nafkah dengan cara menebang pohon tanpa menanam kembali pohon yang telah ditebang.

(2) Samirin telah sedia untuk memberitahukan perlunya hutan tropika dilestarikan. Dia akan mengulangi pelajaran yang dulu membuka matanya mengenai peredaran uap dari kelompok tumbuh-tumbuhan menjadi awan, berubah menjadi hujan dan memberi minum bumi.

(TBTAK/PLA-3/2014: 39)

Kutipan tersebut, menunjukkan bahwa Samirin sangat kesel terhadap orang jember yang berpendapat bahwa walaupun pohonnya banyak ditebang itu tidak akan pernah habis dalam waktu dekat, untuk apa ditanami lagi. Menurut Samirin, itu tidak seperti apa yang telah dia pelajari waktu di bangku sekolah dulu. Di pelajaran IPA guru mengajarkan bagaimana hutan itu di rawat dan dilestarikan bukan malah membuat hutan gundul. Hutan memiliki manfaat yang sangat banyak bagi kelangsungan hidup manusia. Seandainya di dunia tidak ada hutan, maka dipastikan dunia akan terasa sangat panas. Persediaan air pun akan cepat habis karena tak adanya hutan sebagai daerah peresapan. Pohon mengandung CO2 (karbondiosida) yang secara tidak langsung membuat manusia menghirupnya, itulah gunanya manusia menanam pohon walau itu didepan rumah mereka sendiri, supaya manusia tidak kekurangan oksigen secara alami.

(3) "Hampir semua penduduk Kintap bekerja di perkayuan,"

Saya sendiri mempunyai penggergajian. Kecil-kecil.

Betul-betul yang dinamakan kaya sumber alam.

(TBTAK/PLA-3/2014: 37)

Kutipan tersebut, menunjukkan bahwa semua anggota transmigrasi yang berada di pulau Kalimantan memanfaatkan pohon ulin sebagai mata pecariannya. Banyak yang berhasil dari anggota trans yang bekerja sebagai penebang kayu ulin. Penebangan pohon ulin pun tidak hanya dilakukan oleh masyarakat indonesia. Perusahaan asing pun ikut campur untuk memanfaatkan hutan kita. Manfaat yang dimiliki kayu ulin sangat besar.

\section{Aspek Perbandingan Nilai Edukatif Penyikapan Manusia Terhadap Lingkungan Alam pada Novel Sri Rinjani Karya Eva Nourma.}

Nilai edukatif penyikapan manusia terhadap lingkungan yang muncul dalam novel Sri Rinjani karya Eva Nourma merujuk pada bagaimana cara tokoh menjaga dan melestarikan lingkungan alam yang terdapat pada pulau Lombok. Persoalan-persoalan yang mengikutinya khususnya persoalan mengenai berbagai hal yang berkaitan dengan aspek nilai edukatif penyikapan manusia terhadap lingkungan alam. Ciri-ciri aspek nilai edukatif yang dihadirkan Eva Nourma dalam novel Sri Rinjani ialah adanya kesadaran tokoh akan lingkungan alam dan pemanfaatannya.

Tokoh Sri Rinjani adalah seorang gadis kecil yang dilahirkan di tanah Lombok tepatnya di lereng gurung Rinjani. Sri Rinjani seorang gadis kecil yang mempunyai banyak mimpi dan berbagai harapan dari seluruh keluargnya untuk bisa membangun desanya jauh lebih baik dan tidak lagi mengalami kemiskinan yang berkepanjangan. Hal tesebut tampak pada kutipan dibawah ini.

(1) Perempuan desa yang diajarkan ketaatan sebagai perempuan oleh bangsanya bernama sasak. Ketaatan kepada alam dan siapa pun yang menemaninya melukis kehidupan.

(SR/PLA-3/2011: 4) 
Kutipan tersebut, menunjukkan bahwa tokoh Sri Rinjani dilahirkan di desa yang berada pada lereng gunung Rinjani. Sri besar di tengah hutan dan pinggir lautan. Sri dibesarkan dengan nilai-nilai kultur yang ada pada tempatnya. Sri juga diajarkan bagaimana cara hidup di alam dan menghargai alam untuk memberikannya kehidupan yang baik. Menjaga dan melestarikan alam menurutnya sangatlah penting karena alam memberikan kita kehidupan seperti sekarang ini. Ketika kita hidup baik dan rukun dengan alam, maka alam akan senang tiasa memberikan kita kenyamanan. Sebelum kakek Sri Rinjani meninggalpun dia menjadi tokoh masyarakat yang sangat dipercaya untuk menangani apapun yang terjadi di desa Perigi. Hal tersebut tampak pada kutipan dibawah ini.

(2) Kakek pun tumbuh menjadi seorang tokoh masyarakat. Ia sangat dihormati karena kemampuannya membaca tanda-tanda alam yang tersembunyi.

(SR/PLA-3/2011: 4)

Kutipan diatas, menunjukkan bahwa keluarga Sri Rinjani merupakan panutan untuk seluruh masyarakat di desa Perigi. Kakeknya Sri sebelum meninggal adalah seorang tokoh masyarakat yang membantu masyarakat dikalah kesusahan dalam mencari nafkah. Kaekknya Sri juga bisa membaca tanda-tanda alam seperti datangnya waktu hujan dan ketika musim panas datang. Tujuannya untuk memberi tahukan kepada masyarakat kapan harus berladang dan melaut. Kondisi alam sangat penting untuk masyarakat Perigi mencari nafkah.

\section{Pembahasan}

A. Aspek Perbandingan Komponen Kealaman yang Diungkapkan dalam Novel Tanah Baru Tanah Air Kedua Karya Nh. Dini dan Novel Sri Rinjani Karya Eva Nourma.

Pada novel Tanah Baru Tanah Air Kedua karya Nh. Dini, lebih banyak menghadirkan bagaimana komponen kealaman yang terjadi di pulau Kalimantan. Sedangkan novel Sri Rinjani karya Eva Nourma, tidak terlalu menghasilkan bagaimana komponen kealaman yang terjadi di pulau Lombok. Nh. Dini membangun karakter tokohnya dengan lebih dominan memiliki kemampuan untuk lebih bisa memanfaatkan komponen alamnya serta waktu dan tempat dengan sebaik mungkin, supaya bisa mencari nafkah dengan baik di pulau Kalimantan

Eva Nourma dalam novel Sri Rinjani juga membangun tokohnya dengan sedikit berbeda dengan Nh. Dini. Nh. Dini melatarkan tokoh Samirin yang asalnya dari Jawa pergi merantau ke pulau Kalimantan untuk memanfaatkan hutan. Sedangkan Eva Nourma menghadirkan tokoh perempuan yang asal-usulnya dari pulau Lombok mengarungi hidupnya dengan kemiskinan di sebuah perkampungan yang jauh dari hiruk piruk perkotaan. Di pulau Lombok tidak banyak yang bisa dihasilkan dalam memanfaatkan komponen alamnya. Ia hanya menghadirkan tokoh perempuan yang mata pencariannya hanya memukul batu apung atau hitam yang ada di sungai dan berladang dengan hasil yang tidak seberapa, serta bekerja sebagai nelayan untuk makan setiap harinya.

\section{B. Aspek Perbandingan Interaksi Tokoh pada Lingkungan yang Diungkapkan dalam Novel} Tanah Baru Tanah Air Kedua Karya Nh. Dini dan Novel Sri Rinjani Karya Eva Nourma.

Aspek interaksi tokoh pada lingkungan lebih banyak di munculkan oleh novel Tanah Baru Tanah Air Kedua karya Nh. Dini ialah hubungan timbal balik antara tokoh. Nh. Dini menggambarkan tokoh Samirin sebagai laki-laki kuat dan pekerja keras, datang merantau ke pulau Kalimantan bukan hanya sebagai guru, tapi ia merangkap menjadi petani yang memanfaatkan hasil bumi yang ada di pulau Kalimantan. Ia selalu berusaha menyesuaikan dirinya di tempat rantauan agar dapat meraih setiap kesempatan untuk memperoleh 
penghasilan. Ia juga selalu bersifat terbuka (transparansi) terhadap orang-orang sekitar. Semua itu adalah cara Nh. Dini merepresentasikan sosok tokoh Samirin dengan cukup baik.

Aspek interaksi tokoh pada lingkungan yang dibangun Eva Nourma dalam Sri Rinjani digambarkan dengan tokoh Sri Rinjani adalah seorang perempuan yang tinggal di suatu desa tempatnya di lereng gunung Rinjani pulau Lombok. Ia sosok perempuan tangguh yang hidup dengan kemiskinan dari zaman penjajahan belanda. Sri menghabiskan waktu hanya untuk bekerja di ladang dan mengembala kambing-kambingnya. Bahkan untuk berinteraksi sama orang lain pun tidak ada waktu untuknya. Itulah sosok Sri Rinjani yang digambarkan oleh Eva Nourma.

C. Aspek Perbandingan Nilai Edukatif Penyikapan Manusia Terhadap Alam yang Diungkapkan dalam Novel Tanah Baru Tanah Air Kedua Karya Nh. Dini dan Novel Sri Rinjani Karya Eva Nourma.

Nilai edukatif yang terkandung dalam novel Tanah Baru Tanah Air Kedua Karya Nh. Dini dan novel Sri Rinjani Karya Eva Nourma. Tidak terlepas dari aspek pelestarian lingkungan alam yang dihadirkan oleh pengarang.

Pada novel Tanah Baru Tanah Air Kedua Karya Nh. Dini lebih menggambarkan tokoh yang mampu memberikan pengaruh yang baik untuk orang lain. Seperti memberikan pengetahuan untuk menjaga dan melestarikan alam. Tokoh yang memberikan pengaruh positif tentang bagaimana cara memanfaatkan hutan dengan baik. Melalui tokoh tersebut, Nh. Dini ingin menunjukkan bahwa melakukan pembabalan hutan terus menerus akan merusak ekosistem hutan dan berdampak pada manusia juga. Hal tersebut tampak pada kutipan-kutipan sebelumnya.

Eva Nourma dalam novel Sri Rinjani lebih menggambarkan tokohnya dari segi yang berbeda. Ia menghadirkan tokoh perempuan yang belajar dari alam bagaimana cara bertahan hidup dengan kemiskinan yang terjadi di pulau Lombok. Berbeda dengan Nh. Dini yang menghadirkan sosok tokoh laki-laki yang memberikan pengaruh baik untuk orang lain, Eva Nourma malah menghadirkan tokoh perempuan yang dari kecil hidup miskin dan tidak melakukan banyak hal untuk orang lain. Waktunya setiap hari hanya ia habiskan untuk ke ladang dan mengembalan kambing-kambingnya di gunung

\section{SIMPULAN DAN SARAN}

\section{A. Simpulan}

Studi perbandingan eksistensi alam dalam novel Tanah Baru Tanah Air Kedua karya Nh. Dini dan novel Sri Rinjani karya Eva Nourma, yang ditandai adanya, perbandingan komponen kealaman yang dibangun oleh Nh. Dini dalam novel Tanah Baru Tanah Air Kedua lebih dominan pada pemanfaatan alam, sedangkan Eva Nourma dalam novel Sri Rinjani tidak terlalu mengandung pemanfaatan. Hal tersebut dikarenakan adanya cara pandang yang berbeda antara sastra nasional dan sastra lokal. Di dalam novel Tanah Baru Tanah Air Kedua, yang lebih mendominasi adalah saling memperngaruhi, saling berkomunikasih, dan tindakan tokoh yang dihadirkan oleh Nh. Dini. Sedangkan dalam Eva Nourma di dalam novel Sri Rinjani lebih menggunakan tindakan dan reasi tokoh pada saat berkomunikasih. Hal itu dikarenakan perbedaan yang ada pada latar penceritaan antara pulau Kalimantan dan pulau Lombok. nilai edukatif penyikapan manusia terhadap alam yang dibangun Nh. Dini dalam novel Tanah Baru Tanah Air Kedua dan Eva Nouma. Nh. Dini mengambarkan tokoh yang mampu melindungi dan menghargai lingkungan alam, karena antara manusia dan alam harus saling membutuhkan satu sama lain, sedangkan dalam Eva Nourma dalam novel Sri Rinjani mengambarkan tokoh yang 
hanya menghargai lingkungan alam saja, karena untuk melindungi alam, pulau Lombok tidak ada yang melakukan pembabalan hutan seperti yang terjadi di pulau Kalimantan.

\section{B. Saran}

Saran untuk pembelajaran, hasil penelitian dapat disederhanakan, sehingga dapat digunakan sebagai referensi dalam mata kuliah sastra bandingan, ilmu alamiah dasar, dan sosiologi sastra yang mengarah pada aspek perbandingan komponen kealam, interaksi tokoh, dan nilai edukati. sastra.

\section{DAFTAR RUJUKAN}

Dwidjoseputro, D. 1991. Ekologi: Manusia dan Lingkunganya. Jakarta: Erlangga.

Dini. Nh. 2014. Tanah Baru Tanah Air Kedua. Bandung: Pustaka Jaya.

Ismawati. 2012. Metodologi Penelitian Ekologi Sastra. Yogyakarta: CAPS (Center For Academic Publishing Service).

Iskandar, Johan. 2001. Manusia Budaya dan Lingkungan, Ekologi Manusia. Bandung: Humaniora Utama Pres (HUP).

Kaswadi. 2016. Paradigma Ekologi dalam Kajian Sastra. Surabaya: UniversitasWijaya Kusumah.

Nourma. Eva. 2011. Sri Rinjani. Pancor Selong Lombok Timur: STKIP Hamzanwadi Press.

Harsono, Via, 2008. Ekologi Umum. New York: World Bank Educaation IX Project.

Meleong, Lexy. (2002). Metodologi Penelitian Kualitatif. Bandung: Remaja

Soerjani, Muhamad. 2009. Pendidikan Lingkungan (Environmental Education). Jakarta: Universitas Indonesia (UI-Pres).

Sugiono. 2010. Metodologi Penelitian Sastra. Yogyakarta: Pustaka Widatama.

Supardi, Imam. 2003. Lingkungan Hidup dan Kelestariannya. Bandung: P.T. Alumni. 